\title{
Kewenangan Penyelesaian Sengketa Tata Usaha Negara Terhadap Putusan Pemberhentian Tidak Dengan Hormat
}

\author{
Muten Nuna \\ Roy Marthen Moonti \\ Arifin Tumuhulawa \\ Dince Aisa Kodai
}

Fakultas Hukum Universitas Gorontalo

Email Korespondensi : mutensnuna@gmail.com

\begin{abstract}
Nowadays, Indonesia as a developing country has been developed in various sectors. Globalization is a process of organizational change from the function of capitalism which is marked by the emergence of the integration of markets and transnational companies and the lagging of supranational institutions. With this, it is possible for it to affect the work patterns of Indonesian society. For this reason, a further legal remedy will be needed if the party that feels disadvantage is not satisfied with the outcome of the dispute resolution that arises due to the development of globalization. The intended legal remedies are administrative efforts as referred to in Article 48 of Law Number 51 of 2009 concerning Amendments to Law Number 9 of 2004 concerning Amendments to Law Number 5 of 1986 concerning State Administrative Court (PTUN). The aim of this article is to find out the authority for dispute resolution of State Administrative Court (PTUN) toward dismissal with no reverence verdict and dispute resolution efforts for State Administrative Court (PTUN) toward dismissal with no reverence verdict. Juridical normative is applied as research method. This research concludes that dispute resolution on personnel is done through the State Administrative Court except it is caused by violations of the disciplinary rules of the State Civil Apparatus which will be resolved through administrative appeals to the Court of Civil Service.
\end{abstract}

Keywords : Authority; Authority for dispute resolution of State Administrative Court; Dismissal with no Reverence.

\begin{abstract}
ABSTRAK
Indonesia sebagai negara yang berkembang, saat ini sedang membangun diberbagai sektor. Globalisasi merupakan proses perubahan organisasi dari fungsi kapitalisme yang ditandai dengan munculnya integrasi pasar dan perusahaan-perusahaan trans nasional dan tertinggalnya institusi supranasional. Dengan adanya hal ini, dimungkinkan akan mempengaruhi pola kerja masyarakat Indonesia, maka dibutuhkan suatu upaya hukum bila pihak yang merasa dirugikan belum merasa puas akan hasil penyelesaian sengketa yang timbul akibat perkembangan globalisasi ini. Upaya hukum yang dimaksud yaitu upaya administratif sebagaimana dalam Pasal 48 Undang-Undang Nomor 51 tahun 2009 Tentang Perubahan atas Undang-Undang Nomor 9 Tahun 2004 tentang Perubahan atas Undang-Undang Nomor 5 Tahun 1986 Tentang Peradilan Tata Usaha Negara (PTUN). Tujuan penulisan artikel ini yaitu untuk mengetahui kewenangan PTUN dalam penyelesaian sengketa tata usaha negara terhadap putusan pemberhentian tidak dengan hormat dan upaya penyelesaiannya sebagai sengketa Tata Usaha Negara Metode penelitian yang digunakan yaitu yuridis normatif. Penyelesaian sengketa kepegawaian diselesaikan melalui Peradilan Tata Usaha Negara, kecuali sengketa kepegawaian sebagai akibat pelanggaran terhadap peraturan disiplin Aparatur Sipil Negara diselesaikan melalui banding administratif kepada Badan Pertimbangan Kepegawaian.
\end{abstract}

Kata kunci : Kewenangan; Penyelesaian Sengketa Tata Usaha Negara ; Pemberhentian Tidak Dengan Terhormat 


\section{Pendahuluan}

Keberadaan hukum dan negara dalam konsepsi negara hukum merupakan dua sisi yang tidak dapat dipisahkan antara satu dengan yang lainnya. Hal ini di karenakan suatu negara yang mengkultuskan sistem ketatanegaraannya sebagai negara hukum tentunya tidak dapat dipisahkan dari eksistensi hukum dalam penyelenggaraan negara dan pemerintahan di negara tersebut. Negara hukum merupakan konsep bernegara yang telah berkembang dari beberapa dekade lalu. Terbukti dari keberadaan pemikiran mengenai konsep-konsep negara hukum yang telah ada dan berkembang jauh sebelum konsep negara hukum telah tersusun dan tertata seperti saat sekarang ini. ${ }^{1}$

Pembentukan suatu negara pada prinsipnya menghendaki terciptanya kemakmuran bagi seluruh rakyat. Hal ini ditegaskan dalam Pembukaan Undang-Undang Dasar Negara Kesatuan Republik Indonesia 1945 bahwa "kemudian dari pada itu untuk membentuk suatu pemerintahan Negara Indonesia yang melindungi segenap bangsa Indonesia dan seluruh tumpah darah Indonesia dan memajukan kesejahteraan umum, mencerdaskan kehidupan bangsa dan ikut melaksanakan ketertiban dunia yang berdasarkan kemerdekaan, perdamaian abadi dan keadilan sosial"'.2

Indonesia sebagai suatu negara hukum, memiliki badan peradilan yang merdeka dalam menyelenggarakan kekuasaan kehakiman guna menegakan hukum dan keadilan. Berdasarkan ketentuan Pasal 24 ayat (1) Undang-Undang Dasar Negara Republik Indonesia Tahun 1945, "Kekuasaan kehakiman merupakan kekuasaan yang merdeka untuk menyelenggarakan peradilan guna menegakkan hukum dan keadilan”. Kompetensi lingkungan badan peradilan diatur dalam Pasal 25 Undang-Undang Nomor 48 Tahun 2009 tentang Kekuasaan Kehakiman. 1). Peradilan umum adalah memeriksa, memutus, dan menyelesaikan pidana dan perdata; 2). Peradilan agama adalah memeriksa, memutus, dan menyelesaikan perkara antara orang-orang yang beragama Islam; 3). Peradilan militer adalah memeriksa, memutus, dan menyelesaikan perkara tindak pidana militer; 4). Peradilan tata usaha negara adalah memeriksa, memutus, dan menyelesaikan sengketa tata usaha negara. Untuk lingkungan peradilan tata usaha negara sebagai sub sistem dari sistem peradilan di Indonesia berdasarkan Undang-Undang Republik Indonesia Nomor 5 tahun 1986 tentang Peradilan Tata Usaha Negara sebagaimana diubah terakhir dengan Undang-Undang Republik Indonesia Nomor 51 tahun 2009 tentang Perubahan Kedua Atas Undang-Undang Republik Indonesia Nomor 5

\footnotetext{
${ }^{1}$ Muten Nuna \& Roy Marthen Moonti, “Kebebasan Hak Sosial-Politik Dan Partisipasi Warga Negara Dalam Sistem Demokrasi Di Indonesia”, Jurnal Ius Constituendum | Volume 4 Nomor 2 Oktober 2019. Hlm. 112.

2 Jupri \& Roy Marthen Moonti, Diskriminasi Hukum Dalam Pemberantasan Korupsi Politik Di Daerah, Dialogia Iuridica, Volume 11 Nomor 1, November 2019, Hlm. 115.
} 
tahun 1986 tentang Peradilan Tata Usaha Negara (UU Peratun) dalam Pasal 47 mengatur tentang kompetensi Pengadilan Tata Usaha Negara (PTUN) dalam sistem peradilan di Indonesia yaitu bertugas dan berwenang memeriksa, memutus, dan menyelesaikan sengketa tata usaha negara. Kewenangan pengadilan untuk menerima, memeriksa, memutus menyelesaikan perkara yang diajukan kepadanya yang dikenal dengan kompetensi atau kewenangan mengadili. ${ }^{3}$

Sengketa Tata Usaha Negara adalah sengketa yang timbul dalam bidang tata usaha negara antara orang atau badan hukum perdata dengan badan atau pejabat tata usaha negara baik di pusat maupun di daerah, sebagai akibat dikeluarkannya keputusan tata usaha negara, termasuk sengketa kepegawaian berdasarkan peraturan perundang-undangan yang berlaku. Jadi objek dari sengketa tata usaha negara adalah Keputusan Tata Usaha Negara (KTUN). Adapun yang dimaksud dengan Keputusan Tata Usaha Negara adalah suatu penetapan tertulis yang dikeluarkan oleh Badan atau Pejabat Tata Usaha Negara yang berisi tindakan hukum tata usaha negara yang berdasarkan peraturan perundang-undangan yang berlaku, yang bersifat konkret, individual, dan final, yang menimbulkan akibat hukum bagi seseorang atau badan hukum perdata. Dengan melihat definisi tersebut, maka yang menjadi sengketa tata usaha negara adalah terbatas pada keputusan tertulis tata usaha negara. Tindakan-tindakan Badan atau Pejabat Tata Usaha Negara di Indonesia yang tanpa keputusan tata usaha negara tidak menjadi obyek sengketa tata usaha negara. Menurut sistem hukum Indonesia, kewenangan untuk menilai perbuatan materiil dari badan atau pejabat tata usaha negara ini tidak termasuk kompetensi PTUN, kewenangan untuk menilai perbuatan ini diserahkan kepada peradilan umum atau perdata, yang didasarkan penafsiran yang luas dari Pasal 1365 KUHPerdata (tentang onrechtmatig daad). Keputusan Tata Usaha Negara tersebut dibatasi dengan pengurangan dalam Pasal 2, penambahan pada Pasal 3 (1), dan limitasi pada Pasal 49. Keputusan Tata Usaha Negara yang bersifat konkret, individual, dan final inilah yang dapat digugat ke PTUN yang kemudian di putus oleh Hakim Tata Usaha Negara. ${ }^{4}$

Sebelum dibentuknya Undang-Undang Republik Indonesia Nomor 30 tahun 2014 tentang Administrasi Pemerintahan, sistem tanggung gugat terhadap pemerintah terkait dengan tanggung jawab hukum (control segi hukum) terhadap tindak pemerintahan (bestuur handelingen) dikategorikan dalam dua jenis tanggung gugat, yaitu tanggung gugat terhadap

\footnotetext{
${ }^{3}$ Yodi Martono Wahyunadi, "Kompetensi Absolut Pengadilan Tata Usaha Negara Dalam Konteks UndangUndang Nomor 30 Tahun 2014 Tentang Administrasi Pemerintahan", Jurnal Hukum Vol. 5 Nomor 1 Maret 2016. Hal 136,

${ }^{4}$ H. Abdul Khair dkk, "Penyelesaian Sengketa Keputusan Tata Usaha Negara Melalui Upaya Banding Administratif”, Jurnal Ilmu Hukum Jatiswara Vol. 31 Nomor 3 November 2016. Hlm. 416
} 
KTUN yang merugikan warga masyarakat dan tanggung gugat terhadap tindakan pemerintah yang dikategorikan sebagai perbuatan melanggar hukum oleh pemerintah (Onrechmatige Overheidsdaad). Perbedaan terhadap dua jenis sistem tanggung gugat pemerintah ini berimplikasi kepada lingkup kompetensi pengadilan dalam menguji dan menetapkan gugatan terhadap pemerintah. Dimana gugatan terhadap terhadap KTUN yang dikeluarkannya pemerintah menyebabkan kerugian pada warga masyarakat diajukan melalui PTUN sedangkan untuk perbuatan pemerintah yang merugikan warga masyarakat atas dasar Onrechmatige Overheidsdaad disalurkan melalui Peradilan Umum (Pengadilan Negeri). Setelah dibentuknya Undang-Undang Republik Indonesia Nomor 30 tahun 2014 tentang Administrasi Pemerintahan, sengketa Onrechmatige Overheidsdaad dialihkan dari peradilan umum kepada PTUN. Sebagaimana dinyatakan dalam ketentuan Pasal 85 UUAP bahwa pengajuan gugatan sengketa administrasi pemerintahan yang sudah didaftarkan pada pengadilan umum tetapi belum diperiksa, dengan berlakunya undang-undang ini dialihkan dan diselesaikan oleh pengadilan, dan pengajuan gugatan sengketa administrasi pemerintahan yang sudah didaftarkan pada pengadilan umum dan sudah diperiksa, dengan berlakunya undang-undang ini tetap diselesaikan dan diputus oleh pengadilan di lingkungan peradilan umum dimana putusan pengadilan sebagaimana dimaksud dilaksanakan oleh pengadilan umum yang memutus. Ketentuan peralihan tentang kewenangan PTUN menyelesaikan sengketa Onrechmatige Overheidsdaad dalam UUAP, sebelumnya telah diatur dalam ketentuan Pasal 142 UU PTUN sebagaimana diatur pula dalam Surat Edaran Mahkamah Agung Nomor 1 Tahun 1991 Tentang Petunjuk Pelaksanaan Ketentuan Peralihan Undang Undang Nomor 5 Tahun 1986, yang menyatakan bahwa Sengketa Tata Usaha Negara yang pada saat terbentuknya pengadilan menurut undang-undang ini belum diputus oleh pengadilan di lingkungan peradilan umum tetap diperiksa dan diputus oleh pengadilan di lingkungan peradilan umum dan sengketa tata usaha negara yang pada saat terbentuknya pengadilan menurut undang-undang ini sudah diajukan kepada pengadilan di lingkungan peradilan umum tetapi belum diperiksa, dilimpahkan kepada pengadilan di lingkungan peradilan tata usaha negara. $^{5}$ Adapun yang menjadi permasalahan dalam penulisan artikel ini yaitu Bagaimana kewenangan PTUN dalam penyelesaian sengketa Tata Usaha Negara dan Bagaimana upaya penyelesaian sengketa Tata Usaha Negara terhadap putusan pemberhentian tidak dengan hormat. Sedangkan tujuan dalam penelitian ini yaitu untuk mengetahui kewenangan PTUN

\footnotetext{
${ }^{5}$ Bambang Arwanto, “Kewenangan PTUN Dalam Menyelesaikan Sengketa Perbuatan Melanggar Hukum Oleh Pemerintah (Onrechmatige Overheidsdaad)”, Jurnal Hukum Jatiswara, Universitas Mataram, hlm. 2-3.
} 
dalam penyelesaian sengketa Tata Usaha Negara terhadap putusan pemberhentian tidak dengan hormat.

\section{Metode Penelitian}

Metode penelitian yang digunakan berupa penelitian hukum yuridis normatif yang merupakan penelitian kepustakaan, yaitu penelitian terhadap bahan hukum primer dan bahan hukum sekunder yang terdiri dari peraturan perundang-undangan dan literatur-literatur terkait untuk memecahkan persoalan hukum atau permasalahan yang akan dibahas.

\section{Analisis dan Pembahasan}

\section{Kewenangan PTUN dalam Penyelesaian Sengketa Tata Usaha Negara}

Peradilan Tata Usaha Negara sesuai dengan tujuan pembentukannya, berfungsi menyelesaian sengketa antara pemerintah dengan warga masyarakat atau badan hukum yakni berupa sengketa yang timbul dari akibat tindakan pemerintah selaku Pejabat Tata Usaha Negara yang dianggap melanggar hak dan kepentingan warga Negara atau badan hukum itu sendiri. Dengan demikian bahwa Peradilan Tata Usaha Negara diadakan dalam rangka memberikan perlindungan kepada rakyat. Dengan demikian fungsi dan tugas Pengadilan Tata Usaha Negara adalah melayani masyarakat pencari keadilan di bidang tata usaha negara, khususnya terhadap keputusan-keputusan pemerintah yang melanggar hukum dan merugikan masyarakat. Melalui Peradilan Tata Usaha Negara rakyat yang dirugikan akibat dikeluarkannya penetapan Pejabat Tata Usaha Negara dapat meminta perlindungan hukum melalui lembaga Pengadilan Tata Usaha Negara sebagaimana diatur dalam Pasal 1 butir 4 Undang-Undang Peradilan Tata Usaha Negara. Sengketa Tata Usaha Negara adalah sengketa yang timbul dalam bidang tata usaha negara antara orang atau badan hukum perdata dengan badan atau pejabat tata usaha negara baik di pusat maupun di daerah sebagai akibat dari dikeluarkannya keputusan tata usaha negara termasuk sengketa kepegawaian berdasarkan peraturan perundang-undangan yang berlaku. ${ }^{6}$

Adaya perubahan konsep hukum yang diatur dalam UU Peratun, memperluas kompetensi PTUN. Perubahan yang paling mendasar menyangkut keputusan tata usaha negara. Selain adanya obyek sengketa baru berupa tindakan faktual, kompetensi PTUN menilai unsur penyalahgunaan wewenang (Pasal 21 UUAP) dan memeriksa permohonan keputusan fiktif positif (Pasal 53 UUAP), serta Kompetensi PTUN terhadap keputusan pejabat atau badan pemerintahan hasil upaya administratif sebagaimana diatur dalam Pasal

\footnotetext{
${ }^{6}$ Ahmad Dahlan Hasibuan, dkk, "Faktor Penyebab Tidak Dilaksanakannya Putusan Pengadilan Tata Usaha Negara Dan Upaya Penanggulangannya (Analisis Kasus Putusan PTUN Medan No: 17/G/2000/PTUNMDN)”, Jurnal Mercatoria, Vol. 6 Nomor 2 Desember 2013. Hlm. 134.
} 
76 ayat (3) UUAP. Unsur-unsur Keputusan Tata Usaha Negara antara yang termuat dalam Pasal 1 angka 9 UU Peratun dengan Pasal 1 angka 7 UUAP berbeda. Keputusan Tata Usaha Negara ada 6 (enam) unsur sedangkan Keputusan Administrasi 3 (tiga) unsur. Perbedaan tersebut membawa konsekuensi luasnya kompetensi PTUN. Sejalan dengan pendapat J.J.H. Brugink semakin banyak unsur dalam suatu obyek sengketa maka semakin kecil ruang lingkup kompetensi pengadilan. Sebaliknya semakin sedikit unsur dalam obyek sengketa semakin luas kompetensi pengadilan. ${ }^{7}$

Undang-Undang Peradilan Tata Usaha Negara mendefinisikan Keputusan Tata Usaha Negara sebagai penetapan tertulis yang dikeluarkan oleh Badan atau Pejabat Tata Usaha Negara yang berisi tindakan hukum tata usaha negara berdasarkan peraturan perundang-undangan yang berlaku yang bersifat konkret, individual dan final serta menimbulkan akibat hukum bagi seseorang atau badan hukum perdata. Unsur-unsur keputusan tata usaha negara pada prinsipnya meliputi $:^{8}$

1) Ditinjau dari segi pembuatnya: dikeluarkan oleh badan atau pejabat tata usaha negara dalam rangka melaksanakan kegiatan yang bersifat eksekutif (urusan pemerintahan).

2) Ditinjau dari segi wujud materiilnya: berisi tindakan hukum tata usaha negara yaitu tindakan hukum administrasi negara yang melaksanakan fungsi untuk menyelenggarakan urusan pemerintahan baik di pusat maupun di daerah.

3) Ditinjau dari segi sifatnya: Konkret, Individual dan Final.

4) Ditinjau dari segi akibatnya: menimbulkan akibat hukum bagi seseorang atau badan hukum perdata.

Sedangkan Pasal 87 Undang-Undang Administrasi Pemerintahan memperluas obyek sengketa di Peradilan Tata Usaha Negara menjadi :

1) Penetapan tertulis yang juga mencakup tindakan faktual.

2) Keputusan Badan dan/atau Pejabat Tata Usaha Negara di lingkungan eksekutif, legislatif, yudikatif, dan penyelenggara negara lainnya.

3) Berdasarkan ketentuan perundang-undangan dan AUPB.

4) Bersifat final dalam arti lebih luas.

5) Keputusan yang berpotensi menimbulkan akibat hukum. Dan/atau

6) Keputusan yang berlaku bagi warga masyarakat.

\footnotetext{
${ }^{7}$ Yodi Martono Wahyunadi, "Kompetensi Absolut Pengadilan Tata Usaha Negara Dalam Konteks UndangUndang Nomor 30 Tahun 2014 Tentang Administrasi Pemerintahan”, Jurnal Hukum Vol. 5 Nomor 1 Maret 2016. Hlm. 141

${ }^{8}$ Tri Cahya Indra Permana, "Peradilan Tata Usaha Negara Pasca Undang-Undang Administrasi Pemerintahan Ditinjau Dari Segi Access To Justice”, Jurnal Hukum dan Peradilan, Vol. 4 Nomor 3 Nobemver 2015. Hlm. 430.
} 
Dengan diberikannya kewenangan untuk menguji tindakan faktual badan atau pejabat pemerintahan secara atributif dari Undang-Undang Administrasi Pemerintahan, maka secara otomatis Yurisprudensi tersebut diatas tidak relevan lagi untuk diikuti. Selanjutnya Hakim Peradilan Tata Usaha Negara haruslah pula dibekali dengan pengetahuan yang cukup bagaimana cara untuk menguji dan menjatuhkan putusan atas tindakan faktual badan atau pejabat pemerintahan. Poin e adalah Keputusan yang berpotensi menimbulkan akibat hukum. Frasa "berpotensi" menunjukan belum adanya akibat hukum. Dikaitkan dengan ketentuan dalam Pasal 53 ayat (1) Undang-Undang Nomor 5 Tahun 1986 tentang Peradilan Tata Usaha Negara, maka hanya orang atau badan hukum perdata yang merasa kepentingannya dirugikan yang dapat diterima legal standingnya. Prinsip tersebut telah berlaku secara universal9 bahwa hanya orang atau badan hukum perdata yang merasa kepentingannya dirugikan yang dapat mengajukan gugatan. Adapun perluasannya diberikan oleh beberapa Undang-Undang tertentu kepada organisasi kemasyarakatan yang karena tujuan didalam Anggaran Dasar atau Anggaran Rumah Tangganya, berhak mewakili masyarakat atau lingkungan. Dari segi yuridis, selain itu frasa "berpotensi" menimbulkan ketidakpastian hukum karena akan sulit bagi para pihak maupun Hakim dari segi pembuktiannya, dari segi sosiologis dikhawatirkan pengadilan akan kebanjiran perkara akibat dari tidak adanya syarat kepentingan yang dirugikan. ${ }^{9}$

Dalam Peraturan Mahkamah Agung RI (PERMA) No. 4 Tahun 2015 Tentang Pedoman Beracara Dalam Penilaian Unsur Penyalahgunaan Wewenang, mengatur pihak dalam permohonan, Badan dan/atau Pejabat Pemerintahan yang merasa kepentingannya dirugikan oleh hasil pengawasan aparat pengawasan intern pemerintah dapat mengajukan permohonan kepada Pengadilan yang berwenang berisi tuntutan agar Keputusan dan/atau Tindakan Pejabat Pemerintahan dinyatakan ada atau tidak unsur penyalahgunaan Wewenang13. Kompetensi PTUN menguji keabsahan tindakan pemerintahan dari segi hukum (legalitas). Konsep penyalahgunaan wewenang dalam UUAP merupakan kesalahan pejabat pribadi (maladministrasi). Untuk itu, tidaklah tepat pertanggungjawaban pribadi menjadi kompetensi PTUN. Selain itu rumusan

\footnotetext{
${ }^{9}$ Tri Cahya Indra Permana, "Peradilan Tata Usaha Negara Pasca Undang-Undang Administrasi Pemerintahan Ditinjau Dari Segi Access To Justice”, Jurnal Hukum dan Peradilan, Vol. 4 Nomor 3 Nobemver 2015. Hlm. 431.
} 
penyalahgunaan wewenang dalam Pasal 17 ayat (2) UUAP yaitu sebagai berikut : ${ }^{10}$ (a) larangan melampaui Wewenang; (b) larangan mencampuradukkan Wewenang; dan/atau; (c) larangan bertindak sewenang-wenang.

Undang-Undang Administrasi Pemerintahan memberikan kewenangan kepada PTUN untuk menilai ada atau tidaknya unsur penyalahgunaan wewenang yang dilakukan oleh badan atau pejabat pemerintahan. Ketentuan tersebut diatur didalam Pasal 21 Undang-Undang Administrasi Pemerintahan. Pasal 21 ayat (2) Undang-Undang Nomor 30 Tahun 2014 menyebutkan: "Badan dan/atau Pejabat Pemerintahan dapat mengajukan permohonan kepada Pengadilan untuk menilai ada atau tidak ada unsur penyalahgunaan wewenang dalam keputusan dan/atau tindakan”. Beleid tersebut muncul sebagai akibat dari tidak adanya forum pembelaan bagi badan atau pejabat pemerintahan yang diduga telah melakukan penyalahgunaan wewenang selain di ranah hukum pidana dan yang bersangkutan merasa menjadi korban kriminalisasi terhadap kebijakan pejabat publik. ${ }^{11}$

\section{Upaya Penyelesaian Sengketa Tata Usaha Negara terhadap Putusan Pemberhentian Tidak Dengan Hormat}

Penjelasan Pasal 129 Undang-Undang Nomor 5 Tahun 2014 disebutkan juga dalam ayat (1) bahwa yang dimaksud "Sengketa Pegawai ASN" adalah sengketa yang diajukan oleh pegawai ASN terhadap keputusan yang dilakukan oleh Pejabat Pembina Kepegawaian terhadap seorang pegawai. Sejarahnya permasalahan Sengketa kepegawaian sebelum diaturnya undang undang yang baru nomor 5 Tahun 2014, maka status quo dari ketentuan sengketa kepegawaian di atur dalam Pasal 35 Undang-Undang Nomor 8 Tahun 1974 tentang Pokok-Pokok Kepegawaian. Di dalamnya menyatakan penyelesaian sengketa di bidang kepegawaian dilakukan melalui peradilan untuk itu, sebagai bagian dari Peradilan Tata Usaha Negara, Undang-Undang Nomor 51 Tahun 2009 tentang Perubahan Kedua Atas Undang-Undang Nomor 5 Tahun 1986 tentang Peradilan Tata Usaha Negara, Peraturan Pemerintah Nomor 53 Tahun 2010 tentang Disiplin Pegawai Negeri Sipil. Sengketa kepegawaian merupakan salah satu bagian dari sengketa Tata Usaha Negara (TUN) dankeputusan/penetapan di bidang kepegawaian

\footnotetext{
${ }^{10}$ Yodi Martono Wahyunadi, “Kompetensi Absolut Pengadilan Tata Usaha Negara Dalam Konteks UndangUndang Nomor 30 Tahun 2014 Tentang Administrasi Pemerintahan”, Jurnal Hukum Vol. 5 Nomor 1 Maret 2016. Hlm. 142.

${ }^{11}$ Tri Cahya Indra Permana, "Peradilan Tata Usaha Negara Pasca Undang-Undang Administrasi Pemerintahan Ditinjau Dari Segi Access To Justice”, Jurnal Hukum dan Peradilan, Vol. 4 Nomor 3 Nobemver 2015. Hlm. 432.
} 
merupakan objek dari Peradilan Tata UsahaNegara (PERATUN). Pasal 1 angka 4 Undang-Undang Nomor 5 Tahun 1986, merumuskan pengertian Sengketa Tata Usaha Negara adalah sengketa yang timbul dalam bidang Tata Usaha Negara antara orang atau Badan Hukum perdata dengan Badan atau Pejabat Tata Usaha Negara, baik di pusat maupun di daerah, sebagai akibat dikeluarkannya keputusan TUN. Keputusan Tata Usaha Negara merupakan penetapan tertulis yang dilakukan oleh Negara atau pejabat yang berwenang, berisi tindakan hukum berdasarkan praturan perundang-undangan bersifat konkrit, individual dan final. ${ }^{12}$

Bagi Aparatur Sipil Negara (ASN) yang telah melakukan suatu kejahatan atau tindak pidana dalam jabatan ASN tersebut akan ditindaklanjuti oleh pihak yang berwajib untuk itu ASN tersebut akan diberhentikan sementara dari jabatannya untuk kepentingan peradilan seorang ASN yang didakwa telah melakukan suatu kejahatan/pelanggaran jabatan dan berkaitan dengan hal itu oleh pihak yang berwajib dikenakan tahanan sementara, mulai saat penahanannya harus dikenakan pemberhentian sementara. Jika sesudah pemeriksaan oleh pihak yang berwajib seorang ASN yang dikenakan pemberhentian sementara peraturan ini ternyata tidak bersalah, maka pegawai tersebut harus segera diangkat dan dipekerjakan kembali pada jabatannya semula. Jika sesudah pemeriksaan ASN yang bersangkutan ternyata dinyatakan bersalah, maka terhadap ASN yang dikenakan pemberhentian sementara harus diambil tindakan pemberhentian. Pemberhentian seorang ASN berdasarkan peraturan ini ditetapkan mulai keputusan Pengadilan atas perkaranya mendapat kekuatan hukum tetap. Jika dikaitkan dengan Peraturan Pemerintah Disiplin ASN, terhadap ASN yang dinyatakan bersalah berdasarkan keputusan pengadilan harus diberhentikan, didalam tingkatan hukuman disiplin ini termasuk dalam hukuman disiplin berat yang salah satu jenisnya adalah pemberhentian tidak dengan hormat sebagai ASN. ${ }^{13}$

Wewenang mengandung arti hak dan kewajiban. Hak berisi kebebasan untuk melakukan atau tidak melakukan tindakan tertentu atau menuntut pihak lain untuk melakukan tindakan tertentu. Kewajiban memuat keharusan untuk melakukan atau tidak melakukan tindakan tertentu. Dalam hukum administrasi negara wewenang pemerintahan yang bersumber dari peraturan perundang-undangan diperoleh melalui cara-cara yaitu atribusi, delegasi dan mandat. Prinsip negara hukum bahwa setiap tindakan haruslah

\footnotetext{
${ }^{12}$ Robinsar Marbun, “Transformasi Upaya Administratif Dalam Penyelesaian Sengketa Kepegawaian”, Jurnal Yuridis Vol. 4 No. 2, Desember 2017. hlm. 209.

${ }^{13}$ Rusnin, "Pemberhentian Dengan Tidak Hormat Pegawai Aparatur Sipil Negara (Tinjauan Undang-Undang No. 5 Tahun 2014)”, Jurnal Transformasi Administrasi Volume 09 Nomor 02 Tahun 2019. hlm. 187.
} 
dilandasi dengan hukum atau dengan kata lain peraturan perundangan-undangan sehingga dalam melaksanakan tugas dan fungsinya pejabat yang berwenang menghukum wajib berpedoman pada peraturan perundang-undangan sehingga tindakan pemberian sanksi oleh pejabat yang mengabaikan penerapan sanksi bagi pelanggar disiplin berat pegawai negeri sipil merupakan tindakan yang legal secara hukum karena didasarkan oleh perintah peraturan perundang-undangan. ${ }^{14}$

Sementara dalam Undang-Undang Nomor 30 Tahun 2014 tentang Administrasi Pemerintahan, telah menimbulkan kesan terjadinya pertentangan norma yang mengatur tentang kewenangan untuk menerima, memutus, memeriksa dan menyelesaikan sengketa yang tersedia upaya administratif berupa banding administratif antara PTUN dan PT TUN. Dalam hal demikian akan menjadi permasalahan disaat nantinya akan menyelesaikan perkara-perkara yang demikian, seperti sengketa yang tersedia konsep penyelesaianya melalui Upaya Administratif seperti sengketa kepegawaian. Salah satu konsep penyelesaian sengketa melalui Upaya Administratif adalah penyelesaian sengketa kepegawaian. Sengketa Kepegawaian adalah sengketa/perselisihan yang timbul sebagai akibat ditetapkannya Keputusan Tata Usaha Negara di bidang kepegawaian oleh Badan atau Pejabat yang berwenang mengenai kedudukan, kewajiban, hak dan pembinaan Pegawai Negeri Sipil. Untuk penyelesaian sengketa kepegawaian itu sendiri pada mulanya diatur dalam ketentuan Pasal 35 Undang-Undang Republik Indonesia Nomor 43 Tahun 1999 Tentang Perubahan Atas Undang-Undang Nomor 8 Tahun 1974 Tentang Pokok-Pokok Kepegawaian, yaitu yang menyatakan sebagai berikut: ${ }^{15}$

1. Sengketa kepegawaian diselesaikan melalui Peradilan Tata Usaha Negara.

2. Sengketa kepegawaian sebagai akibat pelanggaran terhadap peraturan disiplin Pegawai Negeri Sipil diselesaikan melalui upaya banding administratif kepada Badan Pertimbangan Kepegawaian.

3. Badan sebagaimana dimaksud dalam ayat (2), ditetapkan dengan Peraturan pemerintah.

Berdasarkan ketentuan tersebut di atas, penyelesaian sengketa kepegawaian diselesaikan melalui Peradilan Tata Usaha Negara, kecuali sengketa kepegawaian sebagai akibat pelanggaran terhadap peraturan disiplin Pegawai Negeri Sipil diselesaikan melalui banding administratif kepada Badan Pertimbangan Kepegawaian. Tentang hal ini sebagaimana telah diatur dalam Peraturan Pemerintah Nomor 53 Tahun 2010 tentang

\footnotetext{
${ }^{14}$ Fahrudin Rasyid, "Pengabaian Penerapan Sanksi oleh Pejabat Berwenang terhadap Pelanggaran Disiplin Berat Pegawai Negeri Sipil”, Legal Research, Faculty of Law Halu Oleo University, Volume 1 Issue 1 April 2019. hlm. 53.

15 Azzahrawi, dkk, “Wewenang Dan Kendala Pengadilan Tata Usaha Negara Dalam Menyelesaikan Sengketa Kepegawaian Setelah Upaya Administratif”, Syiah Kuala Law Journal : Vol. 3, No.2 Agustus 2019. hlm. 206.
} 
Disiplin Pegawai Negeri. Menurut ketentuan Pasal 1 angka 6 Peraturan Pemerintah Nomor 53 Tahun 2010 tentang Disiplin Pegawai Negeri Sipil yang dimaksud dengan Upaya administratif adalah prosedur yang dapat ditempuh oleh ASN yang tidak puas terhadap hukuman disiplin yang dijatuhkan kepadanya berupa keberatan atau banding administratif. Upaya administratif terdiri dari Keberatan dan Banding Administratif sebagaimana diatur dalam Pasal 1 angka 7 dan angka 8 Peraturan Pemerintah Nomor 53 Tahun 2010 tentang Disiplin Pegawai Negeri, yang dimaksud dengan Keberatan adalah upaya administratif yang dapat ditempuh oleh ASN yang tidak puas terhadap hukuman disiplin yang dijatuhkan oleh pejabat yang berwenang menghukum kepada atasan pejabat yang berwenang menghukum. Banding administratif adalah upaya administratif yang dapat ditempuh oleh ASN yang tidak puas terhadap hukuman disiplin berupa pemberhentian dengan hormat tidak atas permintaan sendiri atau pemberhentian tidak dengan hormat sebagai PNS yang dijatuhkan oleh pejabat yang berwenang menghukum, kepada Badan Pertimbangan Kepegawaian. Berkaitan dengan penyelesaian sengketa kepegawaian melalui Upaya Administratif, maka dengan diundangkannya UndangUndang Nomor 5 Tahun 2014 tentang Aparatur Sipil Negara juga telah menghadirkan paradigma baru dalam penyelesaiaam sengketa kepegawaian, yakni untuk semua sengketa kepegawaian disebutkan penyelesaiannya melalui upaya administratif, hal ini sebagaimana diatur dalam ketentuan Pasal 129 sebagai berikut : ${ }^{16}$

1. Sengketa Pegawai ASN diselesaikan melalui upaya administratif.

2. Upaya administratif sebagaimana dimaksud pada ayat (1) terdiri dari keberatan dan banding administratif.

3. Keberatan sebagaimana dimaksud pada ayat (2) diajukan secara tertulis kepada atasan pejabat yang berwenang menghukum dengan memuat alasan keberatan dan tembusannya disampaikan kepada pejabat yang berwenang menghukum.

4. Banding administratif sebagaimana dimaksud pada ayat (2) diajukan kepada badan pertimbangan ASN.

5. Ketentuan lebih lanjut mengenai upaya administratif dan badan pertimbangan ASN sebagaimana dimaksud pada ayat (2) dan ayat (4) diatur dengan Peraturan Pemerintah.

Ketentuan Pasal 129 Undang-Undang ASN tersebut diatas, secara tegas juga telah mengatur bahwa penyelesaian sengketa kepegawaian yang disebut dengan sengketa pegawai ASN diselesaikan melalui upaya administratif dengan bentuk keberatan dan banding administratif yang selanjutnya mengenai hal tersebut dalam ketentuan ayat (5) dinyatakan akan diatur lebih lanjut dengan Peraturan Pemerintah, namun sampai saat ini

\footnotetext{
${ }^{16}$ Azzahrawi, dkk, “Wewenang Dan Kendala Pengadilan Tata Usaha Negara Dalam Menyelesaikan Sengketa Kepegawaian Setelah Upaya Administratif”, Syiah Kuala Law Journal : Vol. 3, No.2 Agustus 2019. hlm. 207.
} 
belum ada atau belum dibentuk tentang Peraturan Pemerintah sebagaimana dimaksud, padahal Undang-Undang ASN tersebut telah menggantikan Undang-Undang kepegawaian yang sebelumnya. Inilah yang menjadi salah satu permasalahan juga dalam penyelesaian sengketa kepegawaian yang perlu segera diperhatikan oleh pemerintah untuk menindaklanjuti maksud dari Pasal 129 Undang-Undang ASN tersebut.

\section{Penutup}

Dari pembahasan yang ada maka dapat disimpulkan bahwa Pengadilan Tata Usaha Negara memiliki kewenangan sekaligus berfungsi menyelesaian sengketa antara pemerintah dengan warga masyarakat atau badan hukum yakni berupa sengketa yang timbul dari akibat tindakan pemerintah selaku Pejabat Tata Usaha Negara yang dianggap melanggar hak dan kepentingan warga Negara atau badan hukum itu sendiri. Oleh karena itu, bahwa Peradilan Tata Usaha Negara diadakan dalam rangka memberikan perlindungan kepada rakyat, dimana fungsi dan tugas Pengadilan Tata Usaha Negara adalah melayani masyarakat pencari keadilan di bidang tata usaha negara, khususnya terhadap keputusan-keputusan pemerintah yang melanggar hukum dan merugikan masyarakat. Selanjutnya penyelesaian sengketa kepegawaian diselesaikan melalui Peradilan Tata Usaha Negara, kecuali sengketa kepegawaian sebagai akibat pelanggaran terhadap peraturan disiplin Pegawai Negeri Sipil diselesaikan melalui banding administratif kepada Badan Pertimbangan Kepegawaian.

\section{Ucapan Terima Kasih}

Dengan segala kerendahan hati, izinkan peneliti mengucapkan terima kasih kepada Rektor Universitas Gorontalo Dr. Ibrahim Ahmad, SH.,MH, yang selalu mensupport serta memberikan nasehat kepada seluruh Dosen termasuk peneliti untuk terus melahirkan karya tulis ilmiah yang bermanfaat bagi pengembangan ilmu pengetahuan, dan juga peneliti mengucapkan terima kasih kepada Lembaga Penelitian, Pengembangan dan Pengabdian pada Masyarakat (LP3M) Universitas Gorontalo, yang selalu mendukung dan membantu peneliti dalam menulis karya ilmiah serta semua pihak yang telah membantu baik materil maupun non materil. 


\section{Buku}

\section{Daftar Pustaka}

Ahmad Dahlan Hasibuan, dkk. (2013). Faktor Penyebab Tidak Dilaksanakannya Putusan Pengadilan Tata Usaha Negara Dan Upaya Penanggulangannya (Analisis Kasus Putusan PTUN Medan No: 17/G/2000/PTUN-MDN), Jurnal Mercatoria, Vol. 6 Nomor 2 Desember.

Azzahrawi, dkk. (2019). Wewenang Dan Kendala Pengadilan Tata Usaha Negara Dalam Menyelesaikan Sengketa Kepegawaian Setelah Upaya Administratif. Syiah Kuala Law Journal : Vol. 3, No.2 Agustus.

Bambang Arwanto. Kewenangan PTUN Dalam Menyelesaikan Sengketa Perbuatan Melanggar Hukum Oleh Pemerintah (Onrechmatige Overheidsdaad), Jurnal Hukum Jatiswara, Universitas Mataram.

Fahrudin Rasyid. (2019). Pengabaian Penerapan Sanksi oleh Pejabat Berwenang terhadap Pelanggaran Disiplin Berat Pegawai Negeri Sipil. Legal Research, Faculty of Law Halu Oleo University, Volume 1 Issue 1 April.

H. Abdul Khair dkk. (2016). Penyelesaian Sengketa Keputusan Tata Usaha Negara Melalui Upaya Banding Administratif. Jurnal Ilmu Hukum Jatiswara Vol. 31 Nomor 3 November.

Jupri \& Roy Marthen Moonti. (2019). Diskriminasi Hukum Dalam Pemberantasan Korupsi Politik Di Daerah, Dialogia Iuridica, Volume 11 Nomor 1, November.

Muten Nuna \& Roy Marthen Moonti. (2019). Kebebasan Hak Sosial-Politik Dan Partisipasi Warga Negara Dalam Sistem Demokrasi Di Indonesia”, Jurnal Ius Constituendum | Volume 4 Nomor 2 Oktober.

Robinsar Marbun. (2017). Transformasi Upaya Administratif Dalam Penyelesaian Sengketa Kepegawaian”, Jurnal Yuridis Vol. 4 No. 2, Desember.

Rusnin. (2019). Pemberhentian Dengan Tidak Hormat Pegawai Aparatur Sipil Negara (Tinjauan Undang-Undang No. 5 Tahun 2014)", Jurnal Transformasi Administrasi Volume 09 Nomor 02.

Tri Cahya Indra Permana. (2015). Peradilan Tata Usaha Negara Pasca Undang-Undang Administrasi Pemerintahan Ditinjau Dari Segi Access To Justice”, Jurnal Hukum dan Peradilan, Vol. 4 Nomor 3 November.

Yodi Martono Wahyunadi. (2016). Kompetensi Absolut Pengadilan Tata Usaha Negara Dalam Konteks Undang-Undang Nomor 30 Tahun 2014 Tentang Administrasi Pemerintahan”, Jurnal Hukum Vol. 5 Nomor 1 Maret 2016. 